\title{
Only One of the Large Plasmids in Rhizobium leguminosarum Strain PRE is Strongly Expressed in the Endosymbiotic State
}

\author{
By A. J. M. KROL†, J. G. J. HONTELEZ AND A. VAN KAMMEN* \\ Department of Molecular Biology, Agricultural University, De Dreijen 11, \\ 6703 BC Wageningen, The Netherlands
}

(Received 22 September 1981; revised 16 March 1982)

\begin{abstract}
Plasmid DNA from six strains of Rhizobium leguminosarum was separated by agarose gel electrophoresis and showed a large variation in the number and size of the plasmids. Blotting on to nitrocellulose and hybridization with a probe containing nif (nitrogen fixation) genes from Rhizobium meliloti demonstrated that all strains contain only one plasmid carrying nif genes. The molecular weights of the nif plasmids ranged between approximately $130 \times 10^{6}$ and $550 \times 10^{6}$. Using DNA-DNA hybridization no homologous sequences were detected between the nif plasmid of strain PRE and the other plasmid present in this strain. Hybridizations with RNA from bacteroids showed that only the nif plasmid is strongly expressed in the endosymbiotic state. No selective amplification of plasmid DNA occurs during the transition of free-living bacteria into bacteroids.
\end{abstract}

\section{INTRODUCTION}

Bacteria of the genus Rhizobium are able to fix nitrogen in the root nodules of leguminous plants. Conjugation experiments have demonstrated that bacterial genes involved in the formation of root nodules are located on a large plasmid in Rhizobium leguminosarum (Johnston et al., 1978). At least part of the structural nif (nitrogen fixation) genes of $R$. leguminosarum also appear to be located on a large plasmid (Nuti et al., 1979). Nif genes and genes involved in nodule formation are located on one of the plasmids occurring in $R$. meliloti (Dénarié et al., 1981). Brewin et al. (1980a) found that nodulating ability and hydrogenase, which enhances the efficiency of nitrogen fixation, were encoded by one of the large plasmids in $R$. leguminosarum. Hooykaas et al. (1981) demonstrated that in $R$. trifolii, at least a part of the structural nif genes, and host specificity with respect to nodulating ability, are located on one plasmid.

Since Rhizobium bacteria contain more than one plasmid, it has been postulated that the larger plasmids may be multimers of the smaller ones (Tichy \& Lotz, 1981) or that the plasmids have otherwise homologous sequences. This would render the bacteria polyploid for certain symbiotic genes. Conversely, the plasmids may be different, perhaps carrying complementary information necessary for the establishment of a nitrogen-fixing nodule. Alternatively, only the plasmid carrying the nodulation and nif genes, may be important for symbiosis, the other plasmids remaining unexpressed in bacteroids. In this paper we describe experiments which support the last hypothesis.

\section{METHODS}

Bacterial strains. The six Rhizobium leguminosarum strains used are listed in Table 1. Strains PRE, PF2, TOM, S310a and P8 are from the Laboratory of Microbiology, Wageningen, The Netherlands. Strain 1001 originates

† Present address: Department of Genetics, Biological Laboratory, Free University, De Boelelaan 1087 , Amsterdam-Buitenveldert, The Netherlands. 
from the Rothamsted collection and was obtained from Dr R. K. Prakash, Department of Biochemistry, Leiden, The Netherlands. All strains except P8 are $\mathrm{Nod}^{+}$and $\mathrm{Fix}^{+}$on Pisum sativum cv. Rondo.

Cultivation of Rhizobium bacteria and pea plants and isolation of bacteroids. These were done as described by Krol et al. (1980).

Plasmid isolation and agarose gel electrophoresis. These were done as described by Casse et al. (1978).

Isolation of plasmid DNA from agarose gels. Large plasmid DNA was isolated from a $0.6 \%(\mathrm{w} / \mathrm{v})$ low-melting agarose gel (Marine Colloids, Rockland, U.S.A.). Plasmid bands were cut out, made up to $0.5 \mathrm{M}-\mathrm{NaCl}$ (from a $5 \mathrm{M}$ stock solution), melted at $65^{\circ} \mathrm{C}$, extracted with phenol/cresol (phenol $/ m$-cresol/hydroxyquinoline; 1000: 140:0.4, by wt) (Wieslander, 1979), and the DNA precipitated with 2 vol. ethanol at $-20^{\circ} \mathrm{C}$. To remove traces of agarose from the DNA the pellet was dissolved in a small volume of $0.25 \mathrm{M}$-ammonium acetate, centrifuged for $5 \mathrm{~min}$ at $18000 \mathrm{~g}$ and the DNA again precipitated from the supernatant with 2 vol. ethanol at $-20^{\circ} \mathrm{C}$.

Southern blotting of large plasmid DNA. Prior to blotting intact plasmids were fragmented by incubating the gel in $0.25 \mathrm{M}-\mathrm{HCl}$ for $20 \mathrm{~min}$ at $20^{\circ} \mathrm{C}$ (Wahl et al., 1979). The gel was transferred to $0.5 \mathrm{M}-\mathrm{NaOH}$, and blotting on to nitrocellulose filters (Sartorius, $0.1 \mu \mathrm{m}$ pore size) was performed essentially according to Southern (1975).

Preparation of filters for hybridization. Total cellular DNA from free living bacteria and from bacteroids was isolated as described before ( $\mathrm{Krol}$ et al., 1980). After $10 \mathrm{~min}$ at $100^{\circ} \mathrm{C}$ in $0.1 \times \mathrm{SSC}(\mathrm{SSC}=0.15 \mathrm{M}-\mathrm{NaCl}$, $0.015 \mathrm{M}$-sodium citrate $\mathrm{pH} 7 \cdot 0)$, portions containing DNA $(10 \mu \mathrm{g})$ were made up to $6 \times \mathrm{SSC}$ and filtered three times through a nitrocellulose filter (Sartorius, $0.1 \mu \mathrm{m}$ ). The filters were then baked at $80^{\circ} \mathrm{C}$ for $2 \mathrm{~h}$.

Plasmids $p S A 30$ and $p R m R 1$. These were obtained from Dr F. M. Ausubel, Harvard University, Cambridge, Mass., U.S.A. Plasmid pSA30 contains the $H D K Y$ operon of Klebsiella pneumoniae, of which gene $H$ codes for the subunits of component II, and genes $D$ and $K$ for the $\alpha$ and $\beta$ subunits of component I of nitrogenase (Cannon et al., 1979). Plasmid pRmR 1 contains DNA from $R$. meliloti homologous to pSA30. Plasmids were isolated as described before (Krol et al., 1980) and in vitro labelled with ${ }^{32} \mathrm{P}$ by nick-translation (Rigby et al. 1977).

Total cellular RNA from bacteroids. This was isolated as described by $\mathrm{Krol}$ et al. (1980) and in vitro labelled with ${ }^{32} \mathrm{P}$ according to Goldbach et al. (1978).

Hybridizations. DNA blots were prehybridized at $63^{\circ} \mathrm{C}$ for at least $6 \mathrm{~h}$ in $3 \times \mathrm{SSC}$ containing SDS $(0 \cdot 1 \%$, w/v), BSA $\left(2 \mu \mathrm{g} \mathrm{m}^{-1}\right)$, polyvinylpyrollidone $\left(2 \mu \mathrm{g} \mathrm{m}^{-1}\right)$ and Ficoll $\left(2 \mu \mathrm{g} \mathrm{ml}^{-1}\right)$ (Denhardt, 1966), supplemented with denatured low molecular weight calf thymus DNA $\left(50 \mu \mathrm{g} \mathrm{m}^{-1}\right)$ and poly(A) $\left(10 \mu \mathrm{g} \mathrm{ml}^{-1}\right)$ (for DNA-DNA hybridizations) or yeast RNA (100 $\mu \mathrm{g} \mathrm{ml}^{-1}$ ) (for DNA-RNA hybridizations). Hybridization was performed in $1 \mathrm{ml}$ prehybridization buffer with in vitro labelled pRmR 1, pSA30, Rhizobium large plasmid DNA, or bacteroid $\mathrm{RNA}$, at $63^{\circ} \mathrm{C}$ for up to $24 \mathrm{~h}$. After hybridization the filters were washed three times for $2 \mathrm{~h}$ in $3 \times \mathrm{SSC}$ at $63^{\circ} \mathrm{C}$ and then dried and autoradiographed using Sakura X-ray film (Konishiroku Photo Ind. Co., Japan). In the DNA-DNA filter hybridization experiments radioactivity was assayed in $8 \mathrm{ml}$ Instafluor (Packard Instruments) in a liquid scintillation counter.

\section{RE S ULT S}

\section{Plasmid content of strains}

Six different isolates of $R$. leguminosarum were compared with regard to their plasmid content (Table 1 ); $R$. leguminosarum PRE is the strain commonly used in our experiments. The other strains may be distinguished from PRE by differences in their symbiotic properties such as the shape of the bacteroids (PF2 and P8), ability to nodulate $P$. sativum cv. Afghanistan (TOM), possession of a hydrogenase (S310a), or absence of nitrogen fixation (P8). Electrophoresis in $0.6 \%(\mathrm{w} / \mathrm{v})$ agarose gels showed that the six isolates also differ in plasmid content (Fig. 1, lanes $a$ ). PRE, PF2 and 1001 each carry two plasmids, S310a three, P8 four and TOM probably also four, two of which are probably of similar size (the latter conclusion is based on the much stronger fluorescence of the middle band). The molecular weights of the plasmids in each strain were estimated by comparing their electrophoretic mobility in agarose gels with those of the two plasmids of PRE, for which molecular weights of approximately $230 \times 10^{6}$ and $500 \times 10^{6}$ have been determined $(\mathrm{H}$. V. Tichy \& W. Lotz, personal communication). The molecular weights of the different plasmids (Table 1) vary widely, from approximately $130 \times 10^{6}(1001)$ to $600 \times 10^{6}(\mathrm{~S} 310 \mathrm{a})$. In five strains a plasmid with a molecular weight of 500-550 $\times 10^{6}$ was found, and in four strains a plasmid with a molecular weight of $200-240 \times 10^{6}$. No plasmids of exactly the same size were found in any of the strains. 
Table 1. Properties of the R. leguminosarum strains

$\mathrm{Nod}^{+}, \mathrm{Fix}^{+}$and Hup ${ }^{+}$indicate possession of nodulation ability, nitrogen fixation and hydrogen uptake, respectively.

\begin{tabular}{ll} 
Strain & \multicolumn{1}{c}{$\begin{array}{c}10^{-6} \times \text { Approx. size } \\
\text { of plasmids }\end{array}$} \\
PRE & $230^{*}, 500$ \\
PF2 & $240^{*}, 500$ \\
TOM & $180,220,220^{*}, 500$ \\
1001 & $130^{*}, 550$ \\
S310a & $400,550^{*}, 600$ \\
P8 & $150,200,350,400^{*}$
\end{tabular}

\begin{tabular}{|c|c|c|c|}
\hline \multirow[b]{2}{*}{$\begin{array}{c}\text { Bacteroid } \\
\text { shape }\end{array}$} & \multicolumn{2}{|c|}{ Symbiotic properties on host plant } & \multirow[b]{2}{*}{ Remarks } \\
\hline & $\begin{array}{l}\text { Pisum sativum } \\
\text { cv. Rondo }\end{array}$ & $\begin{array}{l}\text { Pisum sativum } \\
\text { cv. Afghanistan }\end{array}$ & \\
\hline $\mathrm{Y}$ & $\mathrm{Nod}^{+} \mathrm{Fix}^{+} \mathrm{Hup}$ & Nod- & \\
\hline Spheroplasts & $\mathrm{Nod}^{+} \mathrm{Fix}^{+} \mathrm{Hup}^{-}$ & Nod- & Broughton et al. (1980) \\
\hline $\mathrm{Y}$ & Nod $^{+}$Fix $^{+}$Hup $^{-}$ & $\mathrm{Nod}^{+} \mathrm{Fix}^{+} \mathrm{Hup}^{-}$ & Broughton et al. (1980) \\
\hline Y & $\mathrm{Nod}^{+} \mathrm{Fix}^{+}$ & Not tested & Nuti et al. (1977) \\
\hline Y & $\mathrm{Nod}^{+} \mathrm{Fix}^{+} \mathrm{Hup}^{+}$ & $\mathrm{Nod}^{-}$ & \\
\hline Small rods & Nod $^{+}$Fix $^{-}$Hup $^{-}$ & Nod $^{-}$ & $\begin{array}{l}\text { Also } \mathrm{Nod}^{+} \mathrm{Fix}^{-} \text {on } \\
\text { Vicia faba and } \\
\text { Lathyrus sylvestris }\end{array}$ \\
\hline
\end{tabular}

* Indicates plasmid carrying nif genes.

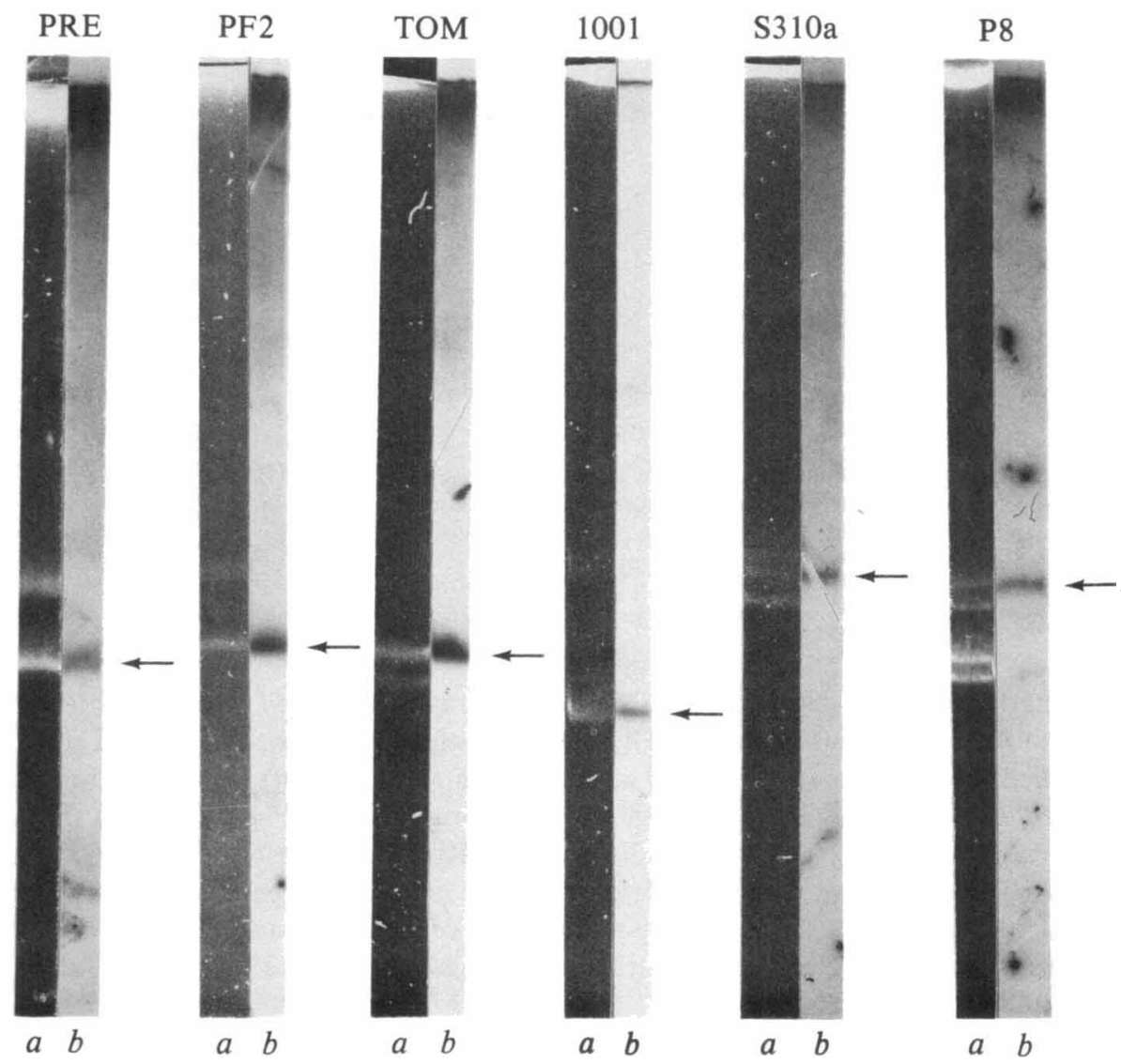

Fig. 1. Hybridization of $R$. leguminosarum plasmid DNA with pRmR1. Plasmid DNA from strains PRE, PF2, TOM, 1001, S310a and P8 was separated by agarose gel electrophoresis and stained with ethidium bromide. The UV-fluorescence pattern is shown in the lanes $a$. After blotting on to nitrocellulose the plasmids were hybridized with in vitro ${ }^{32} \mathrm{P}$-labelled $\mathrm{pRmR} 1$ carrying $n$ if genes from $R$. meliloti. The autoradiograph is shown in the lanes $b$. The arrows indicate the position of the nif plasmids. 


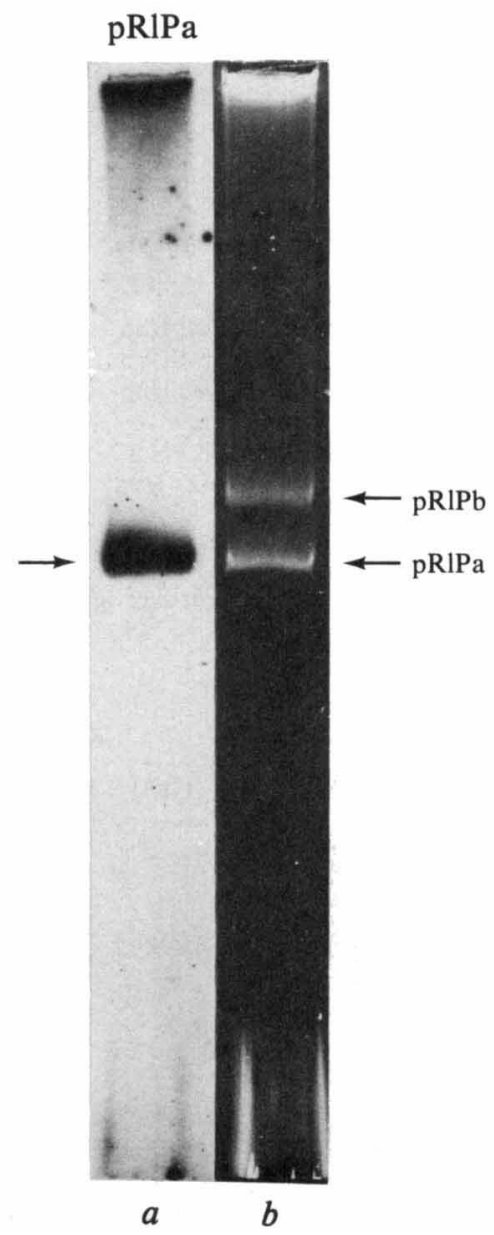

Fig. 2. Comparison of the two plasmids of $R$. leguminosarum strain PRE. The two plasmids of PRE were separated by agarose gel electrophoresis and stained with ethidium bromide; the UV-fluorescence pattern is shown in lane $b$. After blotting on to nitrocellulose the plasmids were hybridized with in vitro ${ }^{32} \mathrm{P}$-labelled pRIPa, isolated from an agarose gel (lane $a$ ).

\section{Hybridization studies}

To determine which of the plasmids in each strain carries nif genes the plasmids were blotted on to nitrocellulose filters and hybridized with in vitro labelled $\mathrm{pRmR} 1 . \mathrm{pRmR} 1$ is a recombinant plasmid containing a $3.9 \mathrm{~kb}$ insert with at least a part of the structural nif genes of $R$. meliloti (Ruvkun \& Ausubel, 1980). The autoradiograph (Fig. 1, lanes $b$ ) shows that in each isolate only one plasmid hybridized with $\mathrm{pRmR} 1$, suggesting that only one of the plasmids carries nif genes. There is a large variation in size between the plasmids carrying nif genes: in 1001 the nif plasmid is nearly half the size of the nif plasmid of PRE, while in S310a it is more than twice as large. Also, strain P8 appeared to have a nif plasmid, although it is Fix $^{-}$on all hosts tested.

\section{Comparison of $p R I P a$ and $p R l P b$}

The two plasmids detected in strain PRE were compared in more detail. The nif plasmid of PRE (referred to as $\mathrm{pRIPa}$ ), was isolated from an agarose gel, labelled in vitro with ${ }^{32} \mathrm{P}$ and used for hybridization with the two separated PRE plasmids blotted on to nitrocellulose. The autoradiograph, shown in Fig. 2, shows that pRIPa only annealed to itself, but not to the larger plasmid (referred to as $\mathrm{pRIPb}$ ). This indicates the absence of appreciable homology between 


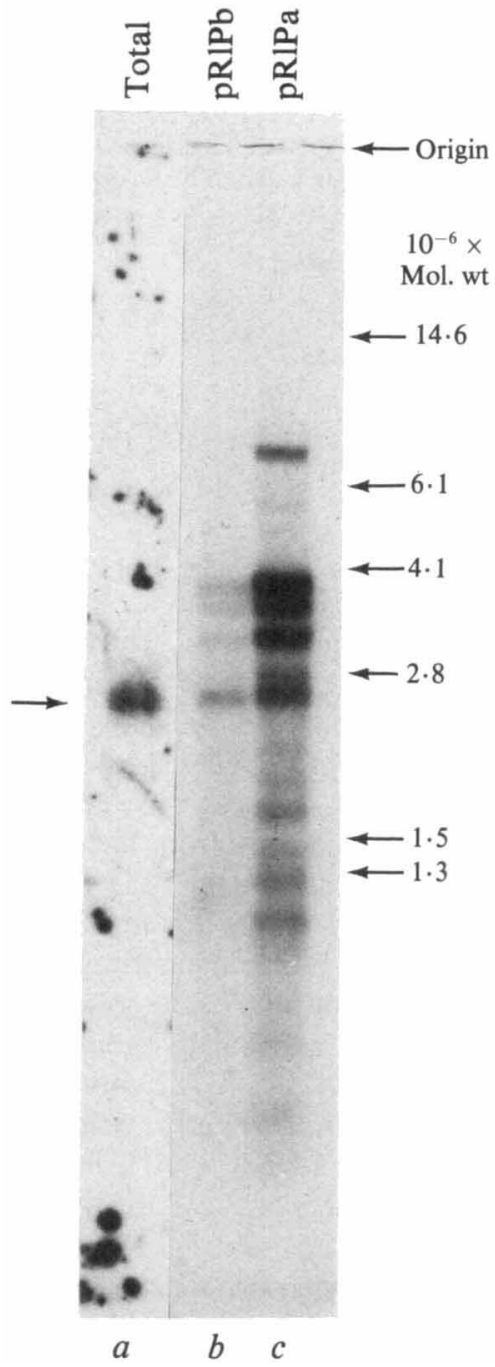

Fig. 3

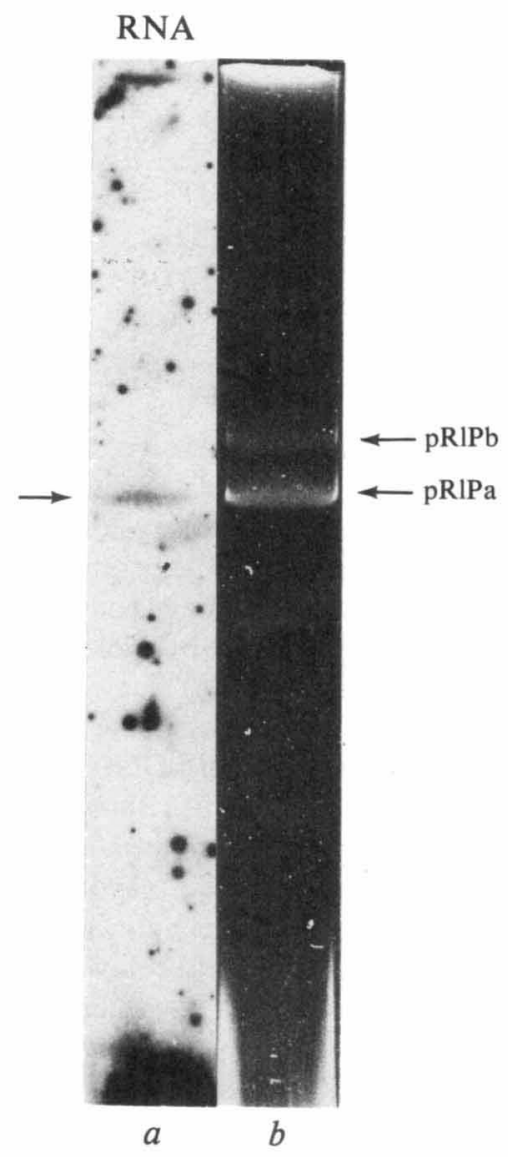

Fig. 4

Fig. 3. Autoradiographs showing hybridization of isolated plasmids of $R$. leguminosarum strain PRE with RNA from bacteroids. Plasmids $\mathrm{pRIPa}$ and $\mathrm{pRIPb}$ (see Fig. 2) were isolated from an agarose gel and digested with $E c o$ RI (lanes $b$ and $c$ ). The fragments were separated by agarose gel electrophoresis, blotted on to nitrocellulose and hybridized with in vitro ${ }^{32} \mathrm{P}$-labelled RNA from bacteroids. The autoradiographs are shown in lanes $b$ and $c$. For comparison total DNA from free-living bacteria was digested with EcoRI and after separation by agarose gel electrophoresis, hybridized with in vitro ${ }^{32} \mathrm{P}$-labelled ribosomal RNA from free living bacteria (lane $a$ ). The arrow at the left indicates the position of the fragment of chromosomal DNA strongly hybridizing with ribosomal RNA. The arrows at the right indicate the position of phage $\lambda$ DNA HindIII fragments used as molecular weight markers.

Fig. 4. Hybridization of plasmid DNA of $R$. leguminosarum strain PRE with RNA from bacteroids. The two plasmids of PRE were separated by agarose gel electrophoresis and stained with ethidium bromide. The UV-fluorescence pattern is shown in lane $b$. After blotting on to nitrocellulose the plasmids were hybridized with in vitro ${ }^{32} \mathrm{P}$-labelled RNA from endosymbiotic bacteroids. The autoradiograph is shown in lane $a$.

the two plasmids. The hybridization of $\mathrm{pRIPb}$ with a blot of the separated plasmids was not done, because $\mathrm{pRlPb}$ is contaminated with $\mathrm{pRIPa}$. This is due to breaking of supercoiled plasmids, causing tailing towards the origin. Therefore a preparation of $\mathrm{pRIPb}$ will always show some hybridization with $\mathrm{pRIPa}$. 


\title{
Table 2. Hybridization of $p S A 30$ with total DNA from R. leguminosarum PRE bacteria and bacteroids
}

\begin{abstract}
Total DNA from bacteria and bacteroids was blotted on to nitrocellulose filters (10 $\mu \mathrm{g}$ DNA per filter), prehybridized with calf thymus DNA and hybridized with in vitro labelled pSA30 (specific activity $7 \times$ $10^{6}$ d.p.m. $\mu \mathrm{g}^{-1}$ ) in $3 \times \mathrm{SSC}$ at $63^{\circ} \mathrm{C}$ for the time indicated. After washing in $3 \times \mathrm{SSC}$ the filters were counted in a liquid scintillation counter. The figures are corrected for background.
\end{abstract}

\begin{tabular}{cccc} 
& \multicolumn{3}{c}{$\begin{array}{c}\text { Amount of pSA30 hybridized to } \\
\text { DNA on filters [d.p.m. }(\mu \mathrm{gNA})^{-1} \text { ] }\end{array}$} \\
DNA on filter & $\overbrace{\text { Time of hybridization }}$ \\
Total bacterial DNA & 43.2 & $14 \mathrm{~h}$ & $24 \mathrm{~h}$ \\
Total bacteroid DNA & 42.7 & 99.0 & 140.9 \\
& & 84.8 & 132.8
\end{tabular}

\section{Transcription of plasmids}

To examine if the extensive transcription of plasmid-borne genes which we found previously (Krol et al., 1980) is from a single plasmid or from both, the two plasmids of PRE were isolated from an agarose gel. The amount of $\mathrm{pRIPb}$ obtained from a gel is less than the amount of $\mathrm{pRIPa}$ : in this experiment approximately $0.5 \mu \mathrm{g} \mathrm{pRIPb}$ and $1 \mu \mathrm{g} \mathrm{pRIPa}$ were isolated. $E$ coRI digests of the plasmids were separated in a $0.7 \%(\mathrm{w} / \mathrm{v})$ agarose gel, blotted on to nitrocellulose filters and hybridized with in vitro ${ }^{32} \mathrm{P}$-labelled RNA from bacteroids. The autoradiograph is shown in Fig. 3, lane $c$. Many fragments of pRlPa (the nif plasmid) hybridize, the pattern being in agreement with that obtained earlier by hybridization of bacteroid RNA with plasmid DNA isolated by $\mathrm{CsCl}$-ethidium bromide centrifugation (Krol et al., 1980). In lane $b$, which shows the Eco RI fragments from $\mathrm{pRIPb}$, the weaker hybridization is probably due to contamination of $\mathrm{pRIPb}$ with $\mathrm{pRIPa}$ as indicated above, since the pattern of bands in lane $b$ corresponds exactly to that of the most strongly hybridizing bands in lane $c$. The more weakly hybridizing bands in lane $c$ are not, or hardly, visible in $b$. An exception is the band a little below the position corresponding to $2.8 \times 10^{6}$ which is more intense in lane $b$ relative to the other bands than in lane $c$. In lane $a$ of Fig. 3 the hybridization of EcoRI-digested total bacterial DNA with purified bacterial ribosomal RNA is shown. It can be seen that ribosomal RNA hybridized strongly to a fragment with a molecular weight of approximately $2.8 \times 10^{6}$, presumably the location of the ribosomal RNA gene on the chromosome. In the EcoRI pattern of $\mathrm{pRIPa}$ and $\mathrm{pRIPb}$ a fragment of similar size also hybridizes strongly with the ribosomal RNA, indicating that the isolated plasmids are contaminated with chromosomal DNA. Therefore the hybridization observed in lane $b$ of Fig. 3 must be attributed to contamination of $\mathrm{pRIPb}$ with $\mathrm{pRIPa}$ and chromosomal DNA. No specific hybridization of bacteroid $\mathrm{RNA}$ with $\mathrm{pRIPb}$ is detectable, suggesting that the large plasmid is not expressed in root nodules. This conclusion was confirmed by an experiment in which plasmids were separated in an agarose gel, blotted on to nitrocellulose and hybridized with ${ }^{32} \mathrm{P}$-labelled bacteroid RNA. The autoradiograph, shown in Fig. 4, exhibits hybridization only with pRIPa.

\section{No selective amplification of nif plasmid DNA}

The use of cloned nif genes makes it possible to examine whether a small amplification of the nif plasmid might occur during the differentiation of bacteria into bacteroids. Therefore total DNA from bacteria and bacteroids was isolated, blotted on to nitrocellulose filters and hybridized with in vitro ${ }^{32} \mathrm{P}$-labelled pSA30. The results (Table 2) show that the rates of hybridization of pSA30 with the two DNAs are equal. This indicates that there is no selective amplification of nif plasmid DNA. 


\section{DIS CUS SION}

Rhizobium strains have been shown to contain several plasmids varying in size (Tichy \& Lotz, 1981). If a CsCl-ethidium bromide gradient is used for the isolation of large plasmids from Rhizobium (Casse et al., 1978; Spitzbarth et al., 1979; Nuti et al., 1979; Krol et al., 1980; Dénarié et al., 1981), a mixture of the plasmids present is obtained, in which the larger plasmids will be under-represented, if they occur at all, because they are more sensitive to shearing forces (Dénarié et al., 1981). To study the different plasmids separately we therefore used agarose gel electrophoresis, which makes it possible to detect the presence and the relative amount of the different plasmids by ethidium bromide staining (Fig. 1). The separated plasmids can be blotted on to a nitrocellulose filter, but it is necessary to reduce the size of the DNA before blotting by incubation of the gel in $0.25 \mathrm{M}-\mathrm{HCl}$ (Wahl et al., 1979). Such blots make it possible to localize sequences on each of the plasmids by annealing with DNA or RNA probes. Using pRmR 1 as a probe we have shown that different strains of $R$. leguminosarum, varying in plasmid content, contain only a single nif plasmid. The nif plasmids differ remarkably in molecular weight: from $130 \times 10^{6}$ in strain 1001 , to $550 \times 10^{6}$ in strain S310a. There is no correlation between the size of the nif plasmid and the phenotype of the symbiosis: PRE and 1001 have similar symbiotic properties, but differ by approximately $100 \times 10^{6}$ in the molecular weight of their nif plasmids. Conversely, PRE, PF2 and TOM differ in symbiotic properties, but have a nif plasmid of approximately the same size. Strain S310a has a very large nif plasmid $\left(550 \times 10^{6}\right)$ and also possesses genes for hydrogen uptake (hup genes). However, Brewin et al. (1980 a) located genes involved in the Hup ${ }^{+}$phenotype on a $190 \times 10^{6}$ plasmid, so that $\mathrm{Hup}^{+}$is not necessarily correlated with a larger size of nif plasmid. Strain P8 is Fix ${ }^{-}$, yet possesses a nif plasmid with a molecular weight of $400 \times 10^{6}$; hence it is unlikely that a large deletion is involved. This strain reduces acetylene at a very low rate (the maximal rate for $\mathrm{P} 8$ is less than $0.1 \%$ of the maximal rate for PRE) and only for a very short period after nodule formation. It also fails to maintain leghaemoglobin synthesis (T. Bisseling, unpublished results). Apparently P8 is defective not in a nif gene but in some other gene involved in establishing effective symbiosis. The significance of the variation in size of the nif plasmids from different strains of $R$. leguminosarum therefore remains a mystery as does the function of the other plasmids present. For strain PRE we have demonstrated that there is no detectable homology between the two plasmids, which would have rendered PRE diploid for certain genes. Brewin et al. $(1980 \mathrm{~b})$ found a similar plasmid pattern for strain TOM to that presented here, only their size estimates were smaller than ours. By plasmid transfer experiments they demonstrated that one of the intermediate-sized TOM plasmids carries genes for nodulation and fixation. By blotting of the plasmids and hybridization with pSA30 it was shown that this plasmid also contains nitrogenase genes (Hombrecher et al., 1981). Four other plasmids of different strains of $R$. leguminosarum or $R$. phaseoli showed the same linkage of $n i f$ genes and nodulating ability. Also in $R$. meliloti (Banfalvi et al., 1981; Rosenberg et al., 1981) and in $R$. trifolii (Hooykaas et al., 1981) nodulation genes and nitrogenase genes appear to be located on a single plasmid.

Of the two plasmids of $R$. leguminosarum strain PRE, only the nif plasmid is strongly expressed in bacteroids, suggesting that only the nif plasmid carries information for the formation of effective nodules. It should be recognized that genes which are only expressed during the early stages of root infection and nodule formation, and also genes showing reduced expression, have probably not been detected in the experiments presented here. Our experiments with strain PRE do not exclude the possibility that with one of the other strains of $R$. leguminosarum or with one of the other Rhizobium species, other plasmids, besides the nif plasmid, are involved in symbiotic nitrogen fixation. Our results suggest, however, that the information for nodule formation is located on a single plasmid and that, in addition to this plasmid, a variable number of cryptic plasmids may occur in Rhizobium.

One reason for the location of symbiotic genes on a single plasmid might be the possibility 
of amplification of this plasmid, resulting in the bacteroids being polyploid for symbiotic genes. During the development of Rhizobium into mature bacteroids the total DNA content per cell increases five- to sevenfold (Bisseling et al., 1977). Reynders et al. (1975) demonstrated that amplification of a part of the DNA during the development of bacteroids does not occur, but since they used reannealing kinetics, a two- or threefold amplification of a small portion of the DNA, e.g. a plasmid, would have remained undetected. Using cloned nif genes it was possible to demonstrate that the copy numbers of nif genes in bacteria and bacteroids are identical, so that there is no amplification of nif plasmids. Thus the strong expression of genes on the nif plasmid is apparently not caused by amplification of nif plasmid DNA.

The authors thank Dr F. M. Ausubel for supplying plasmids pRmR1 and pSA30, Dr H. V. Tichy and Dr W. Lotz for molecular weight determinations of the plasmids of PRE, Dr T. Bisseling for encouraging discussions, Dr R. C. van den Bos for critical reading of the manuscript, A. Hoogeveen for printing the photographs and M. J. van Neerven for preparing the manuscript.

\section{REFERENCES}

Banfalvi, Z., Sankanyan, V., Koncz, C., Kiss, A., Dusha, I. \& Kondorosi, A. (1981). Location of nodulation and nitrogen fixation genes on a high molecular weight plasmid of $R$. meliloti. Molecular and General Genetics 184, 318-325.

Bisseling, T., van den Bos, R. C., van Kammen, A., van Der Ploeg, M., van Duyn, P. \& Houwers, A. (1977). Cytofluorometrical determination of the DNA contents of bacteroids and corresponding broth-cultured Rhizobium bacteria. Journal of General Microbiology 101, 79-84.

Brewin, N.J., De Jong, T. M., Phillips, D. A. \& Johnston, A. W. B. $(1980 a)$. Co-transfer of determinants for hydrogenase activity and nodulation ability in Rhizobium leguminosarum. Nature 288, 77-79.

Brewin, N. J., Beringer, J. E. \& Johnston, A. W. B. $(1980 \mathrm{~b})$. Plasmid-mediated transfer of host-range specificity between two strains of Rhizobium leguminosarum. Journal of General Microbiology $120,413-420$.

Broughton, W. J., van EgeraAt, A. W. S. M. \& Lie, T. A. (1980). Dynamics of Rhizobium competition for nodulation of Pisum sativum cv. Afghanistan. Canadian Journal of Microbiology 26, 562-565.

Cannon, F. C., Riedel, G. E. \& Ausubel, F. M. (1979). Overlapping sequences of Klebsiella pneumoniae nif DNA cloned and characterised. Molecular and General Genetics 174, 59-66.

Casse, F., Boucher, C., Julliot, J. S., Michel, M. \& DÉNARIÉ, J. (1978). Identification and characterization of large plasmids in Rhizobium meliloti using agarose gel electrophoresis. Journal of General Microbiology 113, 229-242.

Dénarié, J., Rosenberg, C., Boistard, P., Truchet, G. \& Casse-Delbart, F. (1981). Plasmid control of symbiotic properties in Rhizobium meliloti. In: Current Perspectives in Nitrogen Fixation. Proceedings of the Fourth International Symposium on Nitrogen Fixation, pp. 137-141. Edited by A. H. Gibson \& W. E. Newton. Amsterdam: Elsevier/ North-Holland Biomedical Press.

DENHARDT, D. T. (1966). A membrane-filter technique for the detection of complementary DNA. Bio- chemical and Biophysical Research Communications 23, 641-646.

Goldbach, R. W., Borst, P., Bollen-De Boer, J. E. \& VAN BRUGGEN, E. F. J. (1978). The organization of ribosomal RNA genes in the mitochondrial DNA of Tetrahymena pyriformis strain GT. Biochimica et biophysica acta 521, 169-186.

Hombrecher, G., Brewin, N. J. \& Johnston, A. W. B. (1981). Linkage of genes for nitrogenase and nodulation ability on plasmids in Rhizobium leguminosarum and $R$. phaseoli. Molecular and General Genetics 182, 133-136.

HooykaAs, P. J. J., van Brussel, A. A. N., DEN Dulk-Ras, H., van Slogteren, G. M. G. \& SCHILPEROORT, R. A. (1981). Sym plasmid of Rhizobium trifolii expressed in different rhizobial species and Agrobacterium tumefaciens. Nature, London 291, 351-353.

Johnston, A. W. B., BEYNON, J. L., BUCHANANWollaston, A. V., Setchell, S. M., Hirsch, P. R. \& BERINGER, J. E. (1978). High frequency transfer of nodulating ability between strains and species of Rhizobium. Nature, London 276, 634-636.

Krol, A. J. M., Hontelez, J. G. J., van den Bos, R. C. \& VAN KAMMEN, A. (1980). Expression of large plasmids in the endosymbiotic form of Rhizobium leguminosarum. Nucleic Acids Research 8, 4337-4347.

Nuti, M. P., Ledeboer, A. M., Lepidi, A. A. \& SCHILPEROORT, R. A. (1977). Large plasmids in different Rhizobium species. Journal of General Microbiology 100, 241-248.

Nuti, M. P., Lepidi, A. A., Prakash, R. K., SChILPERoort, R. A. \& CANNon, F. C. (1979). Evidence for nitrogen fixation (nif) genes on indigenous Rhizobium plasmids. Nature, London $\mathbf{2 8 2}$, 533-535.

Reynders, L., Visser, L., Aalbers, A. M. J., van K AMMEN, A. \& Houwers, A. (1975). A comparison of DNA from free living and endosymbiotic Rhizobium leguminosarum (strain PRE). Biochimica et biophysica acta 414, 206-216.

Rigby, P. W. J., Dieckman, M., Rhodes, C. \& Berg, P. (1977). Labeling deoxyribonucleic acid to a high 
specific activity in vitro by nick translation with DNA polymerase I. Journal of Molecular Biology 113, 237-251.

Rosenberg, C., Boistard, P., Dénarié, J. \& CasseDelbarT, F. (1981). Genes controlling early and late functions in symbiosis are located on a megaplasmid in Rhizobium meliloti. Molecular and General Genetics 184, 326-333.

Ruvkun, G. B. \& Ausubel, F. M. (1980). Interspecies homology of nitrogenase genes. Proceedings of the National Academy of Sciences of the United States of America 77, 191-195.

SoutherN, E. M. J. (1975). Detection of specific sequences among DNA fragments separated by gel electrophoresis. Journal of Molecular Biology 98, 503-517.

Spitzbarth, M., Pühler, A. \& HeumanN, W. (1979).
Characterization of plasmids isolated from Rhizobium meliloti. Archives of Microbiology 121, 1-7.

TICHY, H. V. \& LoTz, W. (1981). Identification and characterization of large plasmids in newly isolated strains of Rhizobium leguminosarum. FEMS Microbiology Letters 10, 203-207.

WAHL, G. M., Stern, M. \& SARK, G. R. (1979). Efficient transfer of large DNA fragments from agarose gels to diazobenzyloxymethyl-paper and rapid hybridization by using dextran sulfate. Proceedings of the National Academy of Sciences of the United States of America 76, 3683-3687.

WIESLANDER, L. (1979). A simple method to recover intact high molecular weight RNA and DNA after electrophoretic separation in low gelling temperature agarose gels. Analytical Biochemistry 98, 304-309. 